\title{
Children and advergame: the role of presence, flow and persuasion knowledge
}

\author{
Santirianingrum Soebandhi* \\ Faculty of Economics and Business, \\ Universitas Narotama, \\ Arief Rachman Hakim St. No. 51, Surabaya, East Java, Indonesia \\ Email: santirianingrum@narotama.ac.id \\ *Corresponding author
}

\section{Sri Hartini and Sri Gunawan}

Faculty of Economics and Business,

Universitas Airlangga,

Airlangga St. No. 4-6, Surabaya, East Java, Indonesia

Email: sri-hartini@feb.unair.ac.id

Email: sgunawan@feb.unair.ac.id

\begin{abstract}
Entertainment offered in advergame can make it difficult for children to understand the message conveyed. Therefore, further investigation on its effectiveness as marketing tool is needed. In this study, we analyse the role of presence, flow, and persuasion knowledge on children's attitudes and intention to buy product advertised in the advergame. Two hundred 10-12-year-old children from public and private schools in Jakarta and Surabaya have participated in this study. The results show that presence has a positive impact on advergame attitude. The prediction stating that flow has a positive impact on advergame and brand attitude is not proven. The increasing persuasion knowledge only shows the impact on brand attitude. Advergame attitude shows a positive impact on brand attitude and not in purchase intention; whereas brand attitude shows a positive impact on children's intention to buy. Based on the findings, suggestions concerning future research and managerial implications are proposed.
\end{abstract}

Keywords: children; presence; flow; persuasion knowledge; attitude; purchase intention; advergame.

Reference to this paper should be made as follows: Soebandhi, S., Hartini, S. and Gunawan, S. (2018) 'Children and advergame: the role of presence, flow and persuasion knowledge', Int. J. Electronic Business, Vol. 14, No. 4, pp.293-308.

Biographical notes: Santirianingrum Soebandhi is a Senior Lecturer at the Universitas Narotama Indonesia. Currently, she is taking her Doctoral in Marketing at the Universitas Airlangga. She received her Bachelor's in Marketing from the Universitas Surabaya and Master's in Commerce from Macquarie University, Australia. Her main interests are in the area of consumer behaviour, advertising and social media. 
Sri Hartini is an Associate Professor at the Universitas Airlangga Indonesia. She holds a Bachelor's in Management from the Universitas Diponegoro, Master's in Management Science from Universitas Airlangga and Doctoral in Economics Science from Universitas Airlangga. Her main areas of interest include marketing management and strategic marketing.

Sri Gunawan is an Associate Professor at the Universitas Airlangga Indonesia. He holds a Bachelor's in Management from the Universitas Gajah Mada, Master's in Commerce from University of New South Wales and Doctoral in Business from Murdoch University. He is actively involved in research and organisation related to management study. His main areas of interest include consumer behaviour, research methods, marketing strategies and e-marketing.

This paper is a revised and expanded version of a paper entitled 'Engaging young consumers with advergames: the effect of presence and flow experience', presented at The 3rd Global Conference on Business, Management and Entrepreneurship (The 3rd GC-BME), Bandung, East Java, Indonesia, 8 August 2018.

\section{Introduction}

Playing video game has been part of children daily activities, supported by the improved access to the digital world. A survey conducted by Indonesian Internet Service Providers Association or APJII (2016) revealed that in Indonesia, the age of internet users is getting younger and children with $<18$ years old prefer to activities such as playing games (eMarketer, 2016). In order to attract children's attention, marketers are demanded to be creative in promoting their products. One of the alternatives is to combine the advertising with the digital game (Steffen et al., 2013) or advergame. Advergame is a game specifically designed as promotion media that emphasising entertainment aspect (Gross, 2010; Terlutter and Capella, 2013; Youn and Mira, 2012). In advergame, advertising messages, logos and characters are integrated into the story or game played (Mizerski, 2009; Mallinckrodt and Mizerski, 2007). Advergame is also considered suitable media to promote products for children because it is more challenging and interactive compared to the brand placement in the movies or TV (Youn and Mira, 2012). In addition, players can spend hours or even months playing their favourite video games, thus, marketers expect longer brand exposure compared to other media (Martí-Parreño et al., 2017).

Advergame is a unique media since it can give immersive experience and the hidden message in advergame can affect attitude and behaviour of its user subconsciously (Staiano and Calvert, 2012; Nuijten et al., 2013). This immersive experience can be gained through presence and flow perceived during playing the game (Weibel and Wissmath, 2011). Presence is the sense of being in a virtual environment through communication technology (Steuer, 1992). Similar to this, the players perceive a feeling as if it were in the game and interact with the contents, objects and characters that did not exist in a physical environment (Biocca, 1997). This feeling emerges an experience between the players and products (virtually) and brings a source of enjoyment and persuasion as the primary goal of advergame (Bracken and Skalski, 2010). Prior studies relating to the effect of presence on attitude and behaviour show various result. However, those studies more concern on teenagers, adult and media such as online advertising (as 
in Debbabi et al., 2013), web marketing (as in Coyle and Thorson, 2001), etc. A sense of presence in advergame in the context of children has not been appearing to be the case of those mentioned studies.

Speaking of flow, it is a state of being in which a person completely involved and immersed in certain activities, leading to time distortion and neglecting other activities that have no correlation to the activities being done at that time (Csikszentmihalyi, 1990; Hoffman and Novak, 2009). In marketing, flow is essential to understand consumers' behaviour in the online environment (Hoffman and Novak, 1996; Obadă, 2013). In addition to resulting enjoyment (Csikszentmihalyi, 1997), flow is also able to create positive outcome since an individual who is being in flow condition will be easier to get persuaded (Hoffman and Novak, 2009). The reason is that, when experiencing flow, an individual tend to accept the message and information delivered (Cooper, 2007). Although that a number of studies have confirmed that flow has a positive influence on attitudes, surprisingly, some studies also show a various result. The study conducted by Wang and Tseng (2010) on university students in Taiwan using a game as learning media found out that flow does not give significant influence on the attitudes toward the game. In addition, as noted by Mau et al. (2008), flow does not have a direct impact on the attitudes toward the brand but it has indirect impact through the attitudes toward the game.

The greater number of advertising formats can cause varied effects on two aspects. First, the way of consumers responds towards the ads. Second, the way of such an ad enables to influence the consumers (Tutaj and van Reijmersdal, 2012). In advergame, the information associated with the brands or products is integrated with the game (Waiguny et al., 2012). This characteristic makes children difficult to differentiate the advertising and the entertaining content. They do not aware that the intention of the advertising is to persuade them to purchase certain products or services (John, 1999). The ability to understand the goal or advertising strategy depends on their persuasion knowledge (PK). Referring to persuasion knowledge model (PKM), if an individual is aware of what they watch is advertising, they will create a negative evaluation towards the advertising or brands advertised (Friestad and Wright, 1994). PK is formed over time and will be used as a defence towards advertising influence. Waiguny and Terlutter (2010) pointed out that if children are aware of the fact that advergame is promotion media, they tend to be sceptical. Other researchers, Mallinckrodt and Mizerski (2007) examining children aged 5-8 years found no link between the increasing of PK and the preference of the brand or intention to ask the products after playing the advergame. Examining the older group of children, it is revealed that the more they recognise the purpose of the persuasion of the advergame, the higher preference they have toward the brand advertised. It indicates that PK has not been certain in the context of advergame. Since such expositions related to PK are unsatisfactory, having the different results in digital context, it is urged to conduct further research, especially in advergame context in children in order to analyse the effectiveness of advergame.

As more popular the advergame, this study is intended to analyse the influence of advergame towards the attitudes and intention of children to purchase the products embedded in advergame by focusing on the experience of presence, flow and PK. Practically, the result of this study enables to provide consideration for the company about the effectiveness of advergame as advertising media for children. 


\section{Theoretical background}

\subsection{Presence, advergame attitudes and brand attitudes}

Presence is the sense of being in a virtual environment and as though the experiences with the object or event in the virtual environment is real (Steuer, 1992; Lombard and Ditton, 1997). In the context of computer game, Nelson et al. (2006) viewed presence as individual transportation in the game ('you are there') or 'the feeling inside the game'. The concept of presence or telepresence initially came from the researchers worked in the field of computer science and engineering (e.g., Minsky, 1980; Steuer, 1992). But then, the study about presence has broadened into many fields including marketing, behavioural and communication sciences (Rodríguez-Ardura and Martínez-López, 2014). This feeling can create the experience between the players and the products (virtually) and create an enjoyment and persuasion as the main goal of advergame (Lombard and Snyder-duch, 2001; Bracken and Skalski, 2010). In marketing literature, the direct experience with the product has a greater influence on the attitudes and belief of consumers compared to the indirect experiences (such as advertising or mouth-to-mouth information) (Debbabi et al., 2013). Actually, advergame is similar to the indirect experience as this experience is obtained through media. However, the developing of technology allows this virtual experience looks like real and enables the players as having interaction with the products/brands in the advergame (Hughes et al., 2002). If the virtual experiences with the products are perceived as a pleasure, it leads to creating positive attitudes towards the advergame and the brand integrated into the advergame (Debbabi et al., 2013; Grigorovici, 2003; Molesworth, 2006). Thereby, the hypotheses proposed are:

$\mathrm{H}_{1} \quad$ Presence positively influence advergame attitudes.

$\mathrm{H}_{2} \quad$ Presence positively influence brand attitudes.

\subsection{Flow, advergame attitudes and brand attitudes}

Generally, game flow is a situation in which a person fully immersed in the game being played. First and foremost, the concept of flow is used to describe a person's pleasurable experience in the context of daily life and work, yet the concept of flow, currently, has been referred to across a variety of fields (Nakamura and Csikszentmihalyi, 2002; Waiguny et al., 2012). Flow has also been studied in the context of information technology and has been recommended to understand consumer behaviour (Hoffman and Novak, 1997, 1996).

During the state of flow, an individual's attention is freely invested in focus attention to the activity, time distortion and loss of self-consciousness (Csikszentmihalyi, 1990). Video game enables to boost this state of flow. The game can keep the players concentrated as they have to be complete and win every level of the game (Youn and Mira, 2012; Kazakova et al., 2012). Being focus on the game makes the players forgetting the time and do not pay attention to surroundings (Hoffman and Novak, 1996; Kazakova et al., 2012).

Advergame is an advertisement that is featured as part of amusement in order to give pleasurable experience for the players. The interaction between the players and the products is virtual (such as collecting the products to add power) and is intentionally 
designed to make exciting experiences for the children. Comparing to other media, advergame has a short duration, relatively simple and easy to play (Nelson and Waiguny, 2012), so flow state can be easily achieved. When a person is experiencing flow, he is likely to accept advergame as a media of entertainment, not as a means of promotion (Lang, 2000).

The experience felt when playing the advergame can create a favourable or unfavourable evaluation. The more players feel entertained when playing the advergame, the positive attitudes will be created as well (Ham et al., 2016) which will be transferred to the brand or product advertised through affective conditioning (Escalas, 2004; Waiguny et al., 2012). This notion is in line with Baker (1999) who suggested that the brands integrated in an advertising format can influence to build the attitude towards brand through the subconsciousness mechanism. Besides, the interaction with product/brand in the advergame is generally a tool for them to win the game (e.g., it can increase the speed, power, defeat the enemy, etc.) so as to generate a positive experience. As a consequence, this experience will always be remembered every time the players see those products/brands and positive feeling toward the brand will also increase (Nelson and Waiguny, 2012). According to the aforementioned explanation, the hypotheses proposed are in the following:

$\mathrm{H}_{3} \quad$ Flow positively influence advergame attitude.

$\mathrm{H}_{4} \quad$ Flow positively influence brand attitude.

\subsection{PK, advergame attitudes and brand attitudes}

A person's ability to recognise the commercial content and to cope with the persuasion attempts is defined as PK (Friestad and Wright, 1994). PK is beliefs within-person who can inform others' attempts to fashion their own (in terms of beliefs, emotions, attitudes, decisions and thinking processes) (Friestad and Wright, 1999). PK is built over time. Consumers learn about tactics used by marketers for those persuasion efforts. This knowledge helps them to recognise, analyse, interpret, evaluate and remember the persuasion and adaptive efforts to respond to such persuasion efforts. As a consequence of this learning/experience, consumers' attitudes and behaviours will also change toward the actions taken by the agent of persuasion (the advertisers or salesperson) (Friestad and Wright, 1994).

In general, the increasing of PK leads to make a negative evaluation about advergame or the brands inside it (Bousch et al., 2009; Waiguny and Terlutter, 2010). In terms of children as the consumers, Rozendaal et al. (2011) highlighted that children's responses to marketing communications depend on their level of understanding about marketing practices. They will use that knowledge as a defence against the effects of advertising (Boerman et al., 2013). Children who know who made and the goals of advergame will tend to be indecisive toward the advergame and the brand embedded (An and Stern, 2011; Verhellen et al., 2014). The more they know (the higher the PK), they will make a negative evaluation for both on advergame and brand integrated into advergame (Friestad and Wright, 1994; Wright et al., 2005). Therefore, the proposed hypotheses are mentioned below:

$\mathrm{H}_{5} \quad$ PK negatively influence advergame attitudes. 
$\mathrm{H}_{6} \quad$ PK negatively influence brand attitude.

\subsection{Advergame attitudes, brands attitudes and purchase intention}

Hoyer and MacInnis (2010) described attitude is as a whole evaluation expressing personal favourable or unfavourable regarding an object, problem, person or an action. This is the reason behind individuals' attitude toward advertising, brands and so forth. Attitude is often used to assess the effectiveness of advertising since it is seen as a strong predictor of intention and behaviour (Sicilia et al., 2006; Chang et al., 2013).

Attitude toward advertising is a personal tendency to give a positive or negative response to advertising stimulus during a certain time of exposure (Lutz, 1985). The effect of attitudes toward advertising on attitude toward brand can be explained by the mechanism of affect transfer (Wise et al., 2008). In other words, if consumers like an advertisement, he or she will tend to also like the product in the ads, leading to influencing consumers' choice and vice versa. For children, the positive attitude toward advertising enables to create a positive evaluation of the brand and affect their demand for the advertised product (Mallinckrodt and Mizerski, 2007). In the context of video game advertising, the better the players' evaluation toward the game, they tend to show positive preference to buy the product advertised (Soebandhi and Andriansyah, 2017; Noor et al., 2013). However, in contrast to the previous studies confirming this positive relationship, the study by Machleit and Wilson (2015) about children aged 5-8 years suggested that attitude toward advertising have no effect on children's intention in purchasing the products in the advergame. Herein, the hypotheses are proposed as follows:

$\mathrm{H}_{7} \quad$ Advergame attitudes positively influence brand attitude.

$\mathrm{H}_{8} \quad$ Advergame attitudes positively influence purchase intention.

$\mathrm{H}_{9} \quad$ Brand attitude positively influence purchase intention.

Figure 1 Conceptual framework

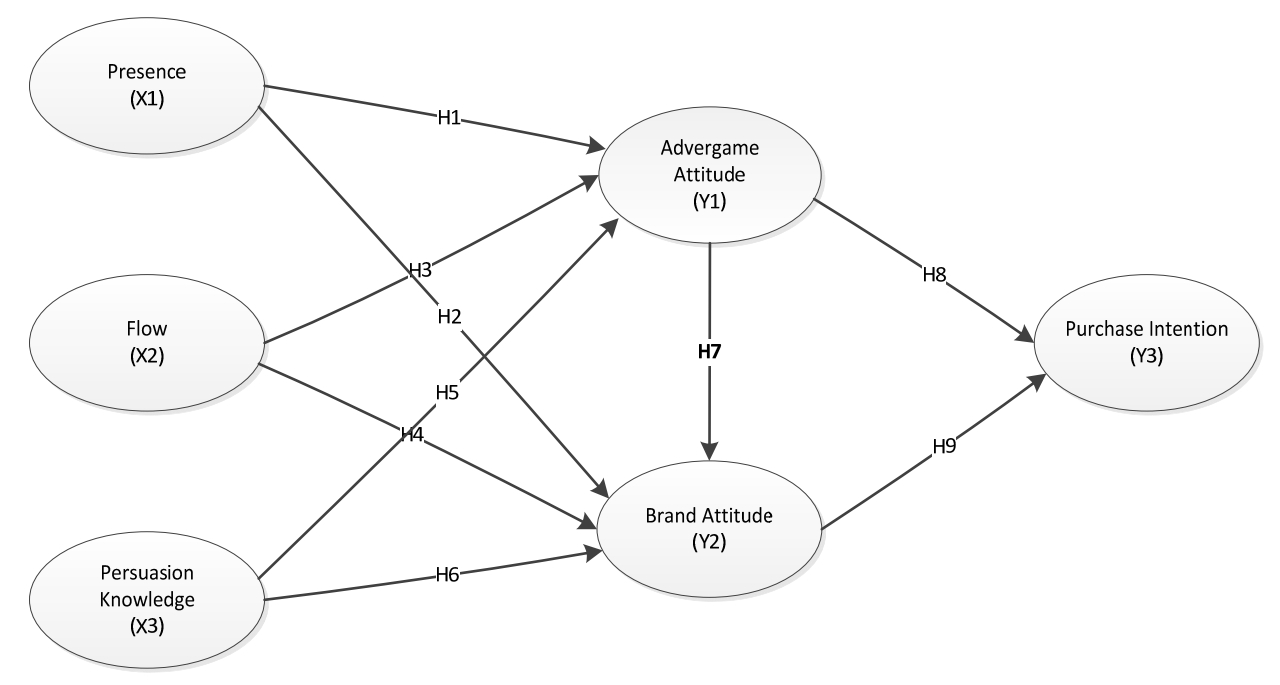




\section{Method}

\subsection{Procedure and design}

An objective evaluation of the respondents is demanded. To support this evaluation, a web-based game, with fictional brand, 'Citos' potato chips, was newly designed for this study (Figure 3). The respondents have not had any experience of playing the game, thus the result will be objective since they will not familiar to both of the brand and the game itself (Schneider et al., 2005). Likewise, the game was designed in simple and easy to play. This aspect is as same as the characteristics of advergame as argued by An and Stern (2011) and Cauberghe and Pelsmacker (2010). Snack was chosen as the product advertised, however, the researchers did not focus on particular products as it is not the centre of the research hypotheses. In this advergame, the players must defeat the enemies and collect Citos chips as much as possible. This product is a major attention of the game and always appears during the game played. Turning to the game genre, arcade was selected because it is considered neutral genre, in which can be played by boys or girls (Gunter, 2016; Saracut, 2014).

A pre-test was held to 30 respondents using these criteria: the age range is the same as the research context (10-12 years old), the respondents like to play video game, and they like the same game genre as the genre used in this study. The aim of this pre-test is to seek if any constraint is found in the game and to review the questions proposed and all aspects related to data collection. For privacy reasons, during observation and data collection process, the names of respondents were not mentioned in the questionnaire. The consent of both the school and the parents to participate was required.

The questions in the questionnaire refer to the prior studies, then, those items were translated and matched with typical children in Indonesia. Those processes, translation and interpretation of the questions, were carried out by two bilingual speakers (English and Indonesia). The questionnaire consists of two parts, the first part describes the respondents' profile and the second part is the question items related to the construct observed. In the beginning part of the questionnaire, narrative about the products (without mentioning the brand) and the method of fulfilling the questionnaire was provided. Appropriate language style, for young children, was also put into consideration.

\subsection{Data}

This study involved 200 respondents of children aged 10-12 years (fifth grade) in the public and private primary school in Jakarta and Surabaya within April-June 2018. As two big cities, Jakarta and Surabaya depict the most saturated media usage in Indonesia, thus, it is able to give illustration of urban users' profile. This age range was administered since in within this age category, children are able to consider some brand attributes (such as: price, complexity, advertising message and taste) and able to give evaluation towards certain products or brand (Rozendaal et al., 2010; Gunter, 2016). It is also noticed that at this age, children also show more consistent brand preference (Bahn, 1986). Notwithstanding children understanding regarding the purpose of ads and their ability to use that notion to reject persuasive message from ads, they will not use this understanding if it is not explicitly delivered (Moore and Rideout, 2007). 


\subsection{Measures}

Children were asked to play the game for about 15 minutes in the class using the existing devices. The link to play the game was provided. Questionnaire filling was assisted by the researchers to help to interpret the questions. Before playing the game, the researchers explained the game and the meaning of each scale. The questionnaire used four-point Likert scale with smiley face icon, starting from an happy until not an happy expression (Reynolds-keefer and Johnson, 2011; Hall et al., 2016) and using response choices: strongly agree-strongly disagree. Whereas, PK was measured using response: certainly know until certainly do not know.

Figure 2 Smiley icon Likert scale (see online version for colours)

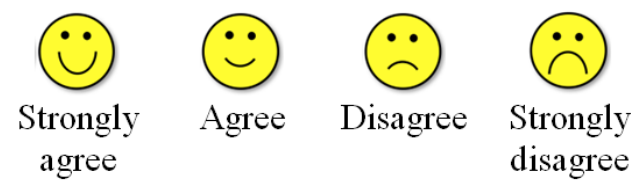

Figure 3 The screen display of advergame 'Citos Ninja' (see online version for colours)

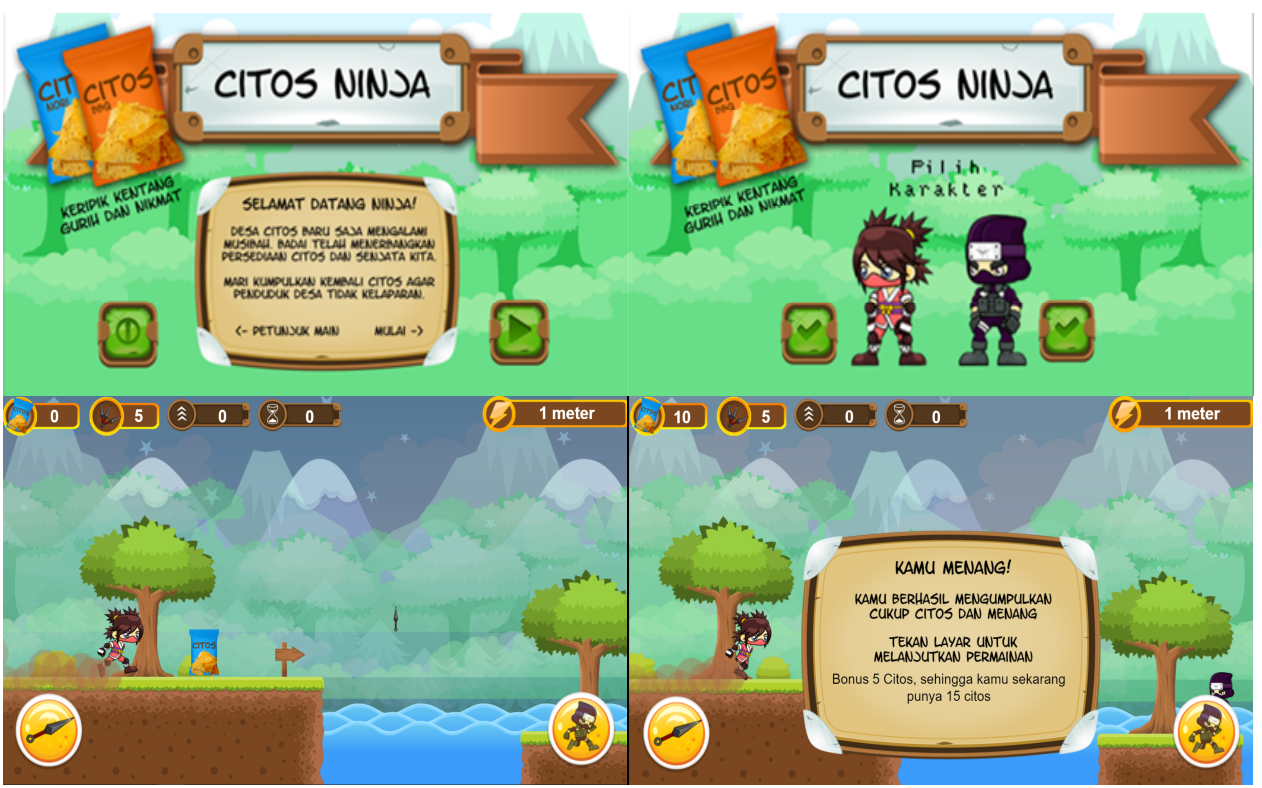

The data were analysed using PLS-SEM with SmartPLS software. There are 16 items of the questionnaire. Two items refer to Hyun and O'Keefe (2012), used to measure presence (e.g., When playing the game, I feel as I am in the action of the game and not just watching the game). Three items are taken from Vanwesenbeeck et al. (2016) for flow (e.g., When playing the game, I am immersed in the game so I start ignoring everything); and two items to measure PK which are taken from Panic et al. (2013) (e.g., I know that 'Citos' chips create this game). For advergame attitude, the four items are 
adopted from Hernandez (2008) (e.g., I like the game I played). Whilst brand attitude was measured using three items from Roedder et al. (1983) (e.g., It seems I will like 'Citos' chips). Lastly, two items from Rozendaal et al. (2013) were used to measure purchase intention (e.g., I will ask my parents to buy 'Citos' chips).

\section{Result}

There are 200 respondents participated that consisting of 92 boys (46\%) and 108 girls $(54 \%)$ with mean age is 10.98 . Most of respondents are from Surabaya $(58 \%, n=115)$. Respondents who are from public primary school is $53.5 \%(\mathrm{n}=107)$ and the rest is from private school $(46.5 \%, \mathrm{n}=93)$. Speaking of the duration in playing game in a week, it is categorised into: everyday $(24 \%, \mathrm{n}=48)$, sometimes/occasionally $(57 \%, \mathrm{n}=114)$ and only in school holiday $(19 \%, \mathrm{n}=38)$.

From 16 items, there are four items with the value of loading factor is below the threshold (0.7), that is, $\mathrm{X}_{2.1}: 0.663, \mathrm{Y}_{1.1}: 0.689, \mathrm{Y}_{1.2}: 0.224$ and $\mathrm{Y}_{2.3}: 0.657$. However, loading indicator between $0.4-0.7$ can still be used if the eliminating factor does not effect on composite reliability (CR) and validity. While the indicator with very-low value $(<0.4)$ should be omitted (Hair et al., 2014). Thus, in this study, only $\mathrm{Y}_{1.2}$ ('In my opinion, the game is boring') is omitted from the model.

The average variance extracted (AVE) and CR is used to measure convergent and discriminant validity. The value of AVE that is between $0.556-0.752$ is higher than the level that can be accepted (0.5). Whereas the value of CR that is between $0.789-0.858$ is greater than 0.7, meaning it has good internal consistency (Hair et al., 2014). To confirm the discriminant validity, the measurement of cross leadings from each indicator is carried out. This measurement exhibits that all loadings of each indicator on its construct are higher than their loadings on other constructs. Further, the calculation of $\mathrm{R}$ square values is $\mathrm{Y}_{1}: 0.207, \mathrm{Y}_{2}: 0.214$ and $\mathrm{Y}_{3}: 0.288$. It indicates that independent variables are a predictor from its dependent variable. Yet, considering that $\mathrm{R}$ square value is low $(<0.5)$, hence those independent variables have a relative slight impact on its dependent variable (Hair et al., 2014, 2011).

Table 1 Value of AVE, CR and R square

\begin{tabular}{llcc}
\hline & AVE & Composite reliability & R square \\
\hline $\mathrm{X}_{1}$ & 0.674 & 0.804 & \\
$\mathrm{X}_{2}$ & 0.653 & 0.847 & \\
$\mathrm{X}_{3}$ & 0.752 & 0.858 & \\
$\mathrm{Y}_{1}$ & 0.556 & 0.789 & 0.207 \\
$\mathrm{Y}_{2}$ & 0.614 & 0.825 & 0.214 \\
$\mathrm{Y}_{3}$ & 0.686 & 0.811 & 0.288 \\
\hline
\end{tabular}

To examine the proposed hypotheses, bootstrapping with a minimum sample of 5.000 and 200 cases are used (Hair et al., 2011). Table 2 concludes the result of path analysis with critical t-values 1.96 ( $\mathrm{sig}$. level $=5 \%$ ). The result shows that $\mathrm{H}_{2}, \mathrm{H}_{3}, \mathrm{H}_{4}, \mathrm{H}_{5}$ and $\mathrm{H}_{8}$ are not supported. 
Table 2 Path analysis

\begin{tabular}{lccc}
\hline Hypothesis & Path & T statistics $(\mid$ OSTERR $\mid)$ & Result \\
\hline $\mathrm{H}_{1}$ & $\mathrm{X}_{1}->\mathrm{Y}_{1}$ & 5.5627 & Supported \\
$\mathrm{H}_{2}$ & $\mathrm{X}_{1}->\mathrm{Y}_{2}$ & 1.7044 & Not supported \\
$\mathrm{H}_{3}$ & $\mathrm{X}_{2}->\mathrm{Y}_{1}$ & 1.9242 & Not supported \\
$\mathrm{H}_{4}$ & $\mathrm{X}_{2}->\mathrm{Y}_{2}$ & 1.7299 & Not supported \\
$\mathrm{H}_{5}$ & $\mathrm{X}_{3}->\mathrm{Y}_{1}$ & 1.1833 & Not supported \\
$\mathrm{H}_{6}$ & $\mathrm{X}_{3}->\mathrm{Y}_{2}$ & 2.2608 & Supported \\
$\mathrm{H}_{7}$ & $\mathrm{Y}_{1}->\mathrm{Y}_{2}$ & 3.5332 & Supported \\
$\mathrm{H}_{8}$ & $\mathrm{Y}_{1}->\mathrm{Y}_{3}$ & 1.3849 & Not supported \\
$\mathrm{H}_{9}$ & $\mathrm{Y}_{2}->\mathrm{Y}_{3}$ & 6.6045 & Supported \\
\hline
\end{tabular}

\section{Discussion}

The first and second hypotheses predict that presence will give impact on how children evaluate advergame and brand. Playing advergame offers a pleasant experience for the players and this feeling enables to a create positive mood (Nelson et al., 2006). Noticing additional result in this study, that is, the sense of presence in the game played only shows a positive impact on advergame attitude, but it does not give impact on their evaluation towards brand embedded in advergame $\left(\mathrm{H}_{2}\right.$ is not supported). This result contrasts to the previous studies claiming that the presence is one of positive psychological response encouraged by the game (Youn and Mira, 2012). This disparity, perhaps, is caused by the extent to which focus of attention can be given by the players during playing the game. The players will focus on the game and remember the experience of playing the game as a valuable experience and will not be mindful of unrelated stimuli (such as integrated brand in the game) (Nelson et al., 2006). Thus, this sense of presence does not encourage the players to like the advertised brand.

Regarding to the third and fourth hypotheses, it reveals that flow does not give impact on attitude towards advergame or attitude towards brand. This is contrary to the previous studies which demonstrated that flow in digital games is the major predictor of attitude and can enhance persuasion (Hernandez, 2011; Waiguny, 2013). This gap possibly happens because, in the context of this study, children are allowed to play the game repeatedly during the duration of the research. It leads to boredom which produce negative effect towards ads and brand stimuli (Cauberghe and Pelsmacker, 2010; Verhellen et al., 2014).

Moreover, according to PKM (Friestad and Wright, 1999), the more children know who and what the purpose of the ads is created, the more negative evaluation towards the ads or brand advertised is resulted. Nevertheless, this study elucidated that the increased PK only illustrates negative impact on attitude towards brand but not in advergame. In other words, the more they know that advergame is a promotional tool, they will be sceptical about the brand (Waiguny et al., 2014). On the other hand, the result of analysis also presents that even if the children know that advergame is one of the promotional media, it does not give impact on their evaluation towards advergame $\left(\mathrm{H}_{5}\right.$ is not supported). Evans and Park (2015) asserted that it occurs because the entertainment and 
enjoyment provided do not trigger doubt or negative attitude towards advergame because they have pleasant experience during playing the advergame.

Based on Table 2, the result of analysis proves that the attitude towards advergame has impact on the attitude towards brand $\left(\mathrm{H}_{7}\right.$ is supported). Similar with the previous studies pronounced that the ads packed in the form of game can create positive evaluation towards the brand advertised and it boosts intention to buy the products advertised (Mallinckrodt and Mizerski, 2007). In spite of that, this study does not reflect the prediction of $\mathrm{H}_{8}$, that is, the attitude towards advergame can influence children's purchase intention. It can be said that anything the players feel when playing advergame does not give impact on their intention in purchasing the product advertised. This can be caused by the difference characteristics between advergame and traditional promotional media, in which advergame more accentuates entertainment rather than product information, more interactive and immersive (Reijmersdal et al., 2012). With the result that the players will not presume advergame as advertisement message, which ignite them to make a purchase (Kusumasondjaja, 2016).

\section{Implications and limitations}

This study broaden our understanding about the role of presence, flow and PK on attitude and children's intention with the exposure of advergame as popular media to advertise products. The previous studies show various results. Described in this study, although the impact on attitude (both towards advergame and brand) and purchase intention is relatively low, but attentions from all parties should be put at the very first stage since the message is hidden in the game played, which enables to influence children without being realised.

The surprising result is that game flow does not give impact on advergame attitudes and the brand attitudes. Conversely, this result does not support Flow theory (Csikszentmihalyi, 1990) and previous studies which confirming the role of flow as the main component in making positive evaluation from players. For the marketers, it is noteworthy for them to consider the importance of duration to finish the game in order to make children not being bored, yielding to their evaluation to the advergame or the brand embedded in it. Furthermore, even as children's understanding that advergame is the advertisement media increases, it does not give impact on their acceptance to the advergame. The entertaining and fun influence offered by the advergame can be as the main reason behind it. This fact can turn benefit for marketers who use advergame as advertisement media because it is well-accepted. However, the marketers also need to consider that advergame is also can boost positive evaluation towards the brands embedded.

In addition to the aforementioned results, this study also has limitations that can be improved in future studies. Explained in this study, respondents are allowed to access the games from their own devices. Some are using smart phones, tablets or laptops. These difference types of device may make a difference experience perceived while playing the game. Subsequent research may be able to use similar electronic devices to provide the same gaming experience. On top of that, the reader should bear in mind that this study was only conducted in large cities in Java Island, it is expected that the future research can add other cities in Indonesia or by comparing rural and urban areas in Indonesia. 


\section{Acknowledgements}

This research has been funded by Doctoral Research Grant from the Direktorat Jenderal Pendidikan Tinggi (Dikti) Republic of Indonesia, in the year 2018.

\section{References}

An, S. and Stern, S. (2011) 'Mitigating the effects of advergames on children', Journal of Advertising, Vol. 40, No. 1, pp.43-56.

APJII (2016) Penetrasi dan Perilaku Pengguna Internet Indonesia, Asosiasi Penyelenggara Pengguna Jasa Internet Indonesia, Jakarta.

Bahn, K.D. (1986) 'How and when do brand perceptions and preferences first form? A cognitive developmental investigation', Journal of Consumer Research, Vol. 13, No. 3, pp.382-393.

Baker, W.E. (1999) 'When can affective conditioning and mere exposure directly influence brand choice?', Journal of Advertising, Vol. 28, No. 4, pp.31-46.

Biocca, F. (1997) 'The cyborg's dilemma: progressive embodiment in virtual environments', Journal of Computer-Mediated Communication, Vol. 3, No. 2.

Boerman, S.C., Reijmersdal, E.A.v. and Neijens, P.C. (2013) 'Appreciation and effects of sponsorship disclosure', in Rosengren, S., Dahlén, M. and Okazaki, S. (Eds.): Advances in Advertising Research (Vol. IV) - The Changing Roles of Advertising, Springer, Sweden.

Bousch, D.M., Friestad, M. and Wright, P. (2009) Deception in the Marketplace: The Psychology of Deceptive Persuasion and Consumer Self Protection, Routledge, New York.

Bracken, C.C. and Skalski, P. (2010) 'Telepresence in everyday life: an introduction', in Bracken, C.C. and Skalski, P. (Eds.): Immersed in Media: Telepresence in Everyday Life, Routledge, New York.

Cauberghe, V. and Pelsmacker, P.D. (2010) 'Advergames', Journal of Advertising, Vol. 39, No. 1, pp.5-18.

Chang, H.H., Rizal, H. and Amin, H. (2013) 'The determinants of consumer behavior towards email advertisement', Internet Research, Vol. 23, No. 3, pp.316-337.

Cooper, J. (2007) Cognitive Dissonance: 50 Years of a Classic Theory, Sage, London.

Coyle, J.R. and Thorson, E. (2001) 'The effects of progressive levels of interactivity and vividness in web marketing sites', Journal of Advertising, Vol. 30, No. 3, pp.65-77.

Csikszentmihalyi, M. (1990) Flow: The Psychology of Optimal Experience, Harper \& Row, New York.

Csikszentmihalyi, M. (1997) Finding Flow: The Psychology of Engagement with Everyday Life, Basic Books, New York.

Debbabi, S., Baile, S., des Garets, V. and Roehrich, G. (2013) 'The impact of telepresence in an online ad on forming attitudes towards the product: the relevance of the traditional experiential approach', Recherche et Applications en Marketing, Vol. 28, No. 2, pp.3-24.

eMarketer (2016) Breaking Down Indonesian Smartphone Habits by Age [online] https://www. emarketer.com/Article/Breaking-Down-Indonesian-Smartphone-Habits-by-Age/1014225 (accessed 12 April 2017).

Escalas, J.E. (2004) 'Imagine yourself in the product: mental simulation, narrative transportation, and persuasion', Journal of Advertising, Vol. 33, No. 2, pp.37-48.

Evans, N.J. and Park, D. (2015) 'Rethinking the persuasion knowledge model: schematic antecedents and associative outcomes of persuasion knowledge activation for covert advertising', Journal of Current Issues \& Research in Advertising, Vol. 36, No. 2, pp.157-176.

Friestad, M. and Wright, P. (1994) 'The persuasion knowledge model: how people cope with persuasion attempts', Journal of Consumer Research, Vol. 2, No. 1, pp.1-31. 
Friestad, M. and Wright, P. (1999) 'Everyday persuasion knowledge', Psychology \& Marketing, Vol. 16, No. 2, pp.185-194.

Grigorovici, D.M. (2003) 'Persuasive effects of presence in immersive virtual environments', in Riva, G., Davide, F. and Ijsselsteijn, W. (Eds.): Being There: Concepts, Effects and Measurement of User Presence in Synthetic Environments, IOS Press, Amsterdam.

Gross, M.L. (2010) 'Advergames and the effects of game-product congruity', Computers in Human Behavior, Vol. 26, No. 6, pp.1259-1265.

Gunter, B. (2016) Kids and Branding in a Digital World, Manchester University Press, Manchester.

Hair, J.F., Hult, G.T.M., Ringle, C.M. and Sarstedt, M. (2014) A Primer on Partial Least Squares Structural Equation Modeling (PLS-SEM), Sage, Thousand Oaks.

Hair, J.F., Ringle, C.M. and Sarstedt, M. (2011) 'PLS-SEM: indeed a silver bullet', The Journal of Marketing Theory and Practice, Vol. 19, No. 2, pp.139-152.

Hall, L.E., Hume, C. and Tazzyman, S. (2016) 'Five degrees of happiness: effective smiley face Likert scales for evaluating with children', IDC '16 Proceedings of the 15th International Conference on Interaction Design and Children, ACM, Manchester, pp.311-321.

Ham, C-D., Yoon, G. and Nelson, M.R. (2016) 'The interplay of persuasion inference and flow experience in an entertaining food advergame', Journal of Consumer Behaviour, Vol. 15, No. 3, pp.239-250.

Hernandez, M.D. (2008) 'Determinants of children's attitudes towards 'advergames': the case of Mexico', Young Consumers, Vol. 9, No. 2, pp.112-120.

Hernandez, M.D. (2011) 'A model of flow experience as determinant of positive attitudes toward online advergames', Journal of Promotion Management, Vol. 17, No. 3, pp.315-326.

Hoffman, D.L. and Novak, T.P. (1996) 'Marketing in hypermedia computer-mediated environments: conceptual foundations', Journal of Marketing, Vol. 60, No. 3, pp.50-68.

Hoffman, D.L. and Novak, T.P. (1997) 'A new marketing paradigm for electronic commerce', The Information Society: An International Journal of Advertising, Vol. 13, No. 1, pp.43-54.

Hoffman, D.L. and Novak, T.P. (2009) 'Flow online: lessons learned and future prospects', Journal of Interactive Marketing, Vol. 23, No. 1, pp.23-34.

Hoyer, W.D. and MacInnis, D.J. (2010) Consumer Behavior, Cengage Learning, Mason, OH.

Hughes, S., Brusilovsky, P. and Lewis, M. (2002) 'Adaptive navigation support in 3D e-commerce activities', in Ricci, F. and Smyth, B. (Eds.): Proceedings of Workshop on Recommendation and Personalization in eCommerce at the 2nd International Conference on Adaptive Hypermedia and Adaptive Web-Based Systems (AH'2002) Proceedings, Málaga, Spain.

Hyun, M.Y. and O'Keefe, R.M. (2012) 'Virtual destination image: testing a telepresence model', Journal of Business Research, Vol. 65, No. 1, pp.29-35.

John, D.R. (1999) 'Consumer socialization of children: a retrospective look at twenty five years of research', Journal of Consumer Research, Vol. 26, No. 3, pp.183-213.

Kazakova, S., Cauberghe, V. and Thijs, D. (2012) 'The effect of flow on implicit memory of in-game brand placements', in Eisend, M., Langner, T. and Okazaki, S. (Eds.): Advances in Advertising Research (Vol. III): Current Insights and Future Trends, Springer Gabler, Wiesbaden.

Kusumasondjaja, S. (2016) 'Respon Konsumen pada Mobile Advergames: Intrusiveness dan Irritation', Jurnal Manajemen Teknologi, Vol. 15, No. 3, pp.206-223.

Lang, A. (2000) 'The limited capacity model of mediated message processing', Journal of Communication, Vol. 50, No. 1, pp.46-70.

Lombard, M. and Ditton, T. (1997) 'At the heart of it all: the concept of presence', Journal of Computer-Mediated Communication, Vol. 3, No. 2.

Lombard, M. and Snyder-duch, J. (2001) 'Interactive advertising and presence', Journal of Interactive Advertising, Vol. 1, No. 2, pp.56-65. 
Lutz, R.J. (1985) 'Affective and cognitive antecedents of attitude toward the ad: a conceptual framework', in Alwitt, L.F. and Mitchell, A.A. (Eds.): Psychological Processes and Advertising Effects: Theory, Research and Application, Erlbaum, Hillsdale, NJ.

Machleit, K.A. and Wilson, R.D. (2015) 'Emotional feelings and attitude toward the advertisement: the roles of brand familarity and repetition', Journal of Advertising, Vol. 17, No. 3, pp.27-35.

Mallinckrodt, V. and Mizerski, D. (2007) 'The effects of playing an advergame on young children's perceptions, preferences, and requests', Journal of Advertising, Vol. 36, No. 2, pp.87-100.

Martí-Parreño, J., Bermejo-Berros, J. and Aldás-Manzano, J. (2017) 'Product placement in video games: the effect of brand familiarity and repetition on consumers' memory', Journal of Interactive Marketing, May, Vol. 38, pp.55-63.

Mau, G., Silberer, G. and Constien, C. (2008) 'Communicating brands playfully', International Journal of Advertising, Vol. 27, No. 5, pp.827-851.

Minsky, M. (1980) 'Telepresence', Omni Magazine, June, pp.45-51 [online] https://web.media.mit.edu/ minsky/papers/Telepresence.html.

Mizerski, D. (2009) The Effects of 'Masked Marketing' in Young Children's Response [online] http://www.ftc.gov/bcp/workshops/sizingup/presentations/Mizerski.pdf (accessed 30 December).

Molesworth, M. (2006) 'Real brands in imaginary worlds: investigating players' experiences of brand placement in digital games', Journal of Consumer Behaviour, Vol. 5, No. 4, pp.355-366.

Moore, E.S. and Rideout, V.J. (2007) 'The online marketing of food to children: is it just fun and games?', Journal of Public Policy \& Marketing, Vol. 26, No. 2, pp.202-220.

Nakamura, J. and Csikszentmihalyi, M. (2002) 'The concept of flow', in Snyder, C.R. and Lopez, S.J. (Eds.): Handbook of Positive Psychology, Oxford University Press, New York.

Nelson, M.R. and Waiguny, M.K.J. (2012) 'Psychological processing of in-game advertising and advergaming: branded entertainment or entertaining persuasion?', in Shrum, L.J. (Ed.): The Psychology of Entertainment Media: Blurring the Lines Between Entertainment and Persuasion, Taylor and Francis, Mahwah, NJ.

Nelson, M.R., Yaros, R.A. and Keum, H. (2006) 'Examining the influence of telepresence on spectator and player processing of real and fictitious brands in a computer game', Journal of Advertising, Vol. 35, No. 4, pp.87-99.

Noor, M.N.M., Sreenivasan, J. and Ismail, H. (2013) 'Malaysian consumers' attitude towards mobile advertising and its impact on purchase intention - a structural equation modeling approach', International Journal of Economics and Statistics, Vol. 3, No. 1, pp.148-155.

Nuijten, K.C.M., Regt, A.d., Calvi, L. and Peeters, A.L. (2013) 'Subliminal advertising in shooter games: recognition effects of textual and pictorial brand logos', International Journal of Arts and Technology, Vol. 6, No. 1, pp.5-21.

Obadă, D.R. (2013) 'Flow theory and online marketing outcomes: a critical literature review', in Marginean, S., Mihaescu, L., Grabara, J. and Stoica, E. (Eds.): International Economic Conference of Sibiu 2013 Post Crisis Economy: Challenges and Opportunities, IECS 2013, Sibiu, pp.550-561.

Panic, K., Cauberghe, V. and De Pelsmacker, P. (2013) 'Comparing TV ads and advergames targeting children: the impact of persuasion knowledge on behavioral responses', Journal of Advertising, Vol. 42, Nos. 2-3, pp.264-273.

Reijmersdal, E.A.v., Rozendaal, E. and Buijzen, M. (2012) 'Brand prominence in advergames: effects on children's explicit and implicit memory', in Langner, T., Okazaki, S. and Eisend, M. (Eds.): Advances in Advertising Research (Vol. III) - Current Insights and Future Trends, Springer Gabler, Wiesbaden.

Reynolds-keefer, L. and Johnson, R. (2011) 'Is a picture is worth a thousand words? Creating effective questionnaires with pictures', Practical Assessment, Research \& Evaluation, Vol. 16, No. 8, pp.1-7. 
Rodríguez-Ardura, I. and Martínez-López, F.J. (2014) 'Another look at 'being there' experiences in digital media: exploring connections of telepresence with mental imagery', Computers in Human Behavior, January, Vol. 30, pp.508-518.

Roedder, D.L., Sternthal, B. and Calder, B.J. (1983) 'Attitude-behavior consistency in children's responses to television advertising', Journal of Marketing Research, Vol. 20, No. 4, pp.337-349.

Rozendaal, E., Buijzen, M. and Valkenburg, P. (2010) 'Comparing children's and adults' cognitive advertising competences in the Netherlands', Journal of Children and Media, Vol. 4, No. 1, pp.77-89.

Rozendaal, E., Lapierre, M.A., Reijmersdal, E.A.v. and Buijzen, M. (2011) 'Reconsidering advertising literacy as a defense against advertising effects', Media Psychology, Vol. 14, No. 4, pp.333-354,.

Rozendaal, E., Slot, N., Reijmersdal, E.A.v. and Buijzen, M. (2013) 'Children's responses to advertising in social games', Journal of Advertising, Vol. 42, Nos. 2-3, pp.142-154.

Saracut, F. (2014) How to Choose the Right Monetization Strategy for Your Mobile Game [online] http://blog.mobiversal.com/monetization-strategy-for-mobile-games.html (accessed 5 February 2018).

Schneider, L-P., Systems, B. and Cornwell, T.B. (2005) 'Cashing in on crashes via brand placement in computer games', International Journal of Advertising, Vol. 24, No. 3, pp.321-343.

Sicilia, M., Ruiz, S. and Reynolds, N. (2006) 'Attitude formation online how the consumer's need for cognition affects the website and attitude towards the brand', International Journal of Market Research, Vol. 48, No. 2, pp.139-154.

Soebandhi, S. and Andriansyah, Y. (2017) 'In-game advertising: analyzing the effects of brand congruity, integration, and prominence towards IGA attitude and purchase intention', Jurnal Manajemen Teknologi, Vol. 16, No. 3, pp.258-270.

Staiano, A.E. and Calvert, S.L. (2012) 'Digital gaming and pediatric obesity: at the intersection of science and social policy', Social Issues Policy Review, Vol. 6, No. 1, pp.54-81.

Steffen, C., Mau, G. and Schramm-klein, H. (2013) 'Who is the loser when I lose the game? Does losing an advergame have a negative impact on the perception of the brand?', Journal of Advertising, Vol. 42, No. 4, pp.183-195.

Steuer, J. (1992) 'Defining virtual reality: dimensions determining telepresence', Journal of Communication, Vol. 42, No. 4, pp.73-93.

Terlutter, R. and Capella, M.L. (2013) 'The gamification of advertising: analysis and research directions of in-game advertising, advergames, and advertising in social network games', Journal of Advertising, Vol. 42, Nos. 2-3, pp.95-112.

Tutaj, K. and van Reijmersdal, E.A. (2012) 'Effects of online advertising format and persuasion knowledge on audience reactions', Journal of Marketing Communications, Vol. 18, No. 1, pp.5-18.

Vanwesenbeeck, I., Ponnet, K. and Walrave, M. (2016) 'Go with the flow: how children's persuasion knowledge is associated with their state of flow and emotions during advergame play', Journal of Consumer Behaviour, Vol. 47, No. 1, pp.38-47.

Verhellen, Y., Oates, C., Pelsmacker, P.D. and Dens, N. (2014) 'Children's responses to traditional versus hybrid advertising formats: the moderating role of persuasion knowledge', Journal of Consumer Policy, Vol. 37, No. 2, pp.235-255.

Waiguny, M.K.J. (2013) 'Investigating the entertainment-persuasion link: can educational games influence attitudes toward products?', in Rosengren, S., Dahlén, M. and Okazaki, S. (Eds.): Advances in Advertising Research (Vol. IV) - The Changing Roles of Advertising, Springer Fachmedien, Wiesbaden.

Waiguny, M.K.J. and Terlutter, R.(2010) 'Entertainment in advergames and its influence on brandrelated outcomes for children', in Terlutter, R., Diehl, S. and Okazaki, S. (Eds.): Advances in Advertising Research, Vol. 1, Gabler, Germany. 
Waiguny, M.K.J., Nelson, M.R. and Terlutter, R. (2012) 'Entertainment matters! The relationship between challenge and persuasiveness of an advergame for children', Journal of Marketing Communications, Vol. 18, No. 1, pp.69-89.

Waiguny, M.K.J., Nelson, M.R. and Terlutter, R. (2014) 'The relationship of persuasion knowledge, identification of commercial intent and persuasion outcomes in advergames - the role of media context and presence', Journal of Consumer Policy, Vol. 37, No. 2, pp.257-277.

Wang, T-L. and Tseng, Y-F. (2010) 'Developing and evaluating a game-based project management learning platform', IEEE EDUCON Education Engineering 2010 - The Future of Global Learning Engineering Education, IEEE, Madrid, pp.1391-1394.

Weibel, D. and Wissmath, B. (2011) 'Immersion in computer games: the role of spatial presence and flow', International Journal of Computer Games Technology.

Wise, K., Bolls, P.D., Kim, H., Venkataraman, A. and Meyer, R. (2008) 'Enjoyment of advergames and brand attitudes', Journal of Interactive Advertising, Vol. 9, No. 1, pp.27-36.

Wright, P., Friestad, M. and Boush, D.M. (2005) 'The development of marketplace persuasion knowledge in children, adolescents, and young adults', Journal of Public Policy \& Marketing, Vol. 24, No. 2, pp.222-233.

Youn, S. and Mira, L. (2012) 'In-game advertising and advergames: a review of the past decade's research', in Rodgers, S. and Thorson, E. (Eds.): Advertising Theory, Routledge, New York. 